\title{
Evaluation of oil shale resources based on geochemistry and logging in Tuanyushan, Qaidam Basin, Northwest China
}

\author{
Jun-Xian Wang ${ }^{(\mathrm{a}, \mathrm{b})}$, Ping-Chang Sun ${ }^{(\mathrm{a}, \mathrm{b}, \mathrm{c})^{*}}$, Zhao-Jun Liu ${ }^{(\mathrm{a}, \mathrm{b})}$, Yin-Bo Xu ${ }^{(\mathrm{d})}$, \\ $\mathrm{Li} \operatorname{Li}^{(a, b)}$
}

(a) College of Earth Sciences, Jilin University, Changchun, Jilin 130061, China

(b) Key Laboratory for Oil Shale and Paragenetic Minerals of Jilin Province, Changchun, Jilin 130061, China

(c) Key Laboratory of Mineral Resources Evaluation in Northeast Asia, Ministry of Natural Resources, Jilin University, Changchun, Jilin 130061, China

(d) Oil and Gas Survey, China Geological Survey, Beijing 100083, China

\begin{abstract}
In this study, oil shale resources in the Middle Jurassic Shimengou Formation in the Tuanyushan area along the northern margin of the Qaidam Basin in Northwest China are evaluated. The total organic carbon (TOC) content of oil shale in the study area is positively correlated with resistivity and negatively correlated with acoustic travel time and natural gamma. Based on TOC and oil yield, as well as the log response differences between the resistivity logging curve, the natural gamma logging curve and the acoustic travel time logging curve of mudstone with differing TOC contents, $\triangle \log R$ and stepwise regression models can be created to quantitatively determine the TOC content of oil shale. The results of the two prediction models and the measured values show the mean absolute deviation (MAD) of the $\Delta \log R$ model to be $0.95 \mathrm{wt} \%$ and the coefficient of determination, $R^{2}, 0.67$. The MAD of the stepwise regression model is $1.15 \mathrm{wt} \%$ and $R^{2}$ is 0.54 . Of these two prediction models, the $\Delta \log R$ model has a higher recognition ability, but the predicted results are easily disturbed by silty mudstone. Therefore, the stepwise regression model is used to quantitatively identify oil shale resources in the study area. The comparison of the predicted and measured oil yields of oil shale from exploratory wells shows their $R^{2}$ to be 0.49. This suggests that in the whole study area, oil shale resources can be identified by the logging curve. Based on log interpretation, the volume method is used to estimate the area's oil shale resources. The results show the oil shale resources in this area to total 392 million tons and converted shale oil resources 24 million tons.
\end{abstract}

Keywords: Qaidam Basin, Middle Jurassic, Shimengou Formation oil shale, logging prediction, quantitative evaluation.

\footnotetext{
* Corresponding author: e-mail sunpingchang711@126.com
} 


\section{Introduction}

China ranks second in the world for oil shale resources, which primarily originate in continental lake basins. Oil shale strata are widely distributed and range in age from the Late Palaeozoic to the Cenozoic [1]. Although China is rich in oil shale resources, due to the low fluctuation of international oil prices and insufficient technological developments in recent years, the resource utilisation rate is low. The primary methods of development are open-pit and underground mining, and the oil product is obtained through dry distillation on the ground. At present, logging technology is being widely applied to the evaluation of hydrocarbon source rocks. Schmoker [2] identified total organic carbon (TOC) content in source rocks through density logging. Fertl and Rieke [3] evaluated fractured shale reservoirs and source rocks by using gamma spectrometry logging. Meyer and Nederlof [4] established linear relationships to identify source rocks through density-resistivity and acoustic travel timeresistivity intersection diagrams. Mendelson and Toksoz [5], Autric and Dumesnil [6] and Hussain [7] employed acoustic, resistivity, natural gamma and neutron density logging methods to identify source rocks through multiple regression, and Passey et al. [8] established the $\Delta \log R$ method to identify hydrocarbon source rocks by logging. In the $\Delta \log R$ method, the porosity log curve (acoustic, density, neutron) and the logarized resistivity logging curve overlap in the resulting picture. Based on the opposite direction of the two curves after superposition, as well as TOC test results, the correlation formula is constructed in the current paper to achieve the required prediction. In addition, Huang and Williamson [9], Yang et al. [10] and Mahmoud et al. [11] used an artificial neural network to quantitatively evaluate source rocks, while $\mathrm{Hu}$ et al. [12] and Jia et al. [13] applied the $\Delta \operatorname{logR}$ method to quantitatively identify oil shale. In general, there can be differentiated four types of oil shale logging identification methods: single factor prediction devised by Schmoker [2] and Fertl and Rieke [3], multivariate regression prediction introduced by Mendelson and Toksoz [5], $\Delta \operatorname{logR}$ method developed by Passey et al. [8] and artificial neural networks created by Huang and Williamson [9].

Different basins have different geological backgrounds and source rock characteristics, which requires the use of different logging models to predict TOC content. Therefore, it is necessary to create a TOC logging prediction model specifically for each study area. The Middle Jurassic Shimengou Formation, located along the northern margin of the Qaidam Basin, is characterised by thick oil shale deposits, a low degree of exploration and the lack of commercial development. Considering this, oil shale logging identification and evaluation is a suitable means for early TOC prediction. Model construction and resource prediction will serve as a basis for further exploration of oil shale in the Qaidam Basin. 


\section{Geological setting}

This study focuses on the Tuanyushan area, a narrow northwest-southeast trending belt with an area of $280 \mathrm{~km}^{2}$, which is located within the Saishiteng Piedmont Depression in the Northern Fault Block Belt in the Qaidam Basin, Northwest China (Fig. 1a, 1b, 1c). The Middle Jurassic stratum in the study area may be up to $1 \mathrm{~km}$ thick and consists of the Lower Dameigou Formation and the Upper Shimengou Formation [14]. The Dameigou Formation is composed mainly of coarse-to-fine siliceous clastic rocks and contains two exploitable coal seam horizons [15]. The Shimengou Formation is the main oil shale sedimentary stratum and can be further divided into the Lower Coalbearing Member $\left(\mathrm{J}_{2} \mathrm{Sh}^{1}\right)$ and the Upper Shale Member $\left(\mathrm{J}_{2} \mathrm{Sh}^{2}\right)$. The Coalbearing Member $\left(\mathrm{J}_{2} \mathrm{Sh}^{1}\right)$ is composed mostly of grey-white medium-to-coarse sandstone, grey siltstone, silty mudstone and carbonaceous shale, with three exploitable coal seam horizons. The Shale Member $\left(\mathrm{J}_{2} \mathrm{Sh}^{2}\right)$ is dominated by grey-brown to grey-black oil shale, grey mudstone and grey-green mudstone and siltstone.

\section{Samples and methods}

Well QCD-2 drilled in the southwestern part of the study area in 2016 revealed the complete formation of $\mathrm{J}_{2} \mathrm{Sh}^{2}$. The well contained a complete coring with logging, including resistivity, acoustic, density and natural gamma logging curves. Oil shale and mudstone samples were taken at depths of 65 to $270 \mathrm{~m}$. Thirty mixed samples taken at every meter were selected for TOC and oil yield tests. Based on coring from this well, a model of oil shale identification by logging was constructed. In addition, wells Y24-2 and KT-23 were selected to carry out point sample oil yield tests, with the test points totalling 65 , to verify the accuracy of the model. The oil yield from the low-temperature retorting at about $520{ }^{\circ} \mathrm{C}$ was measured by Fischer assay in a Fushun retort [16]. The total organic carbon (TOC) was determined in samples pre-treated with concentrated HCI by using a Leco CS-230 elemental analyser [17]. Pyrolysis was carried out using a Rock-Eval 6. Depending on TOC content, $10-50 \mathrm{mg}$ of pulverized sample ( $\leq 200 \mathrm{mesh}$ ) was gradually heated in an inert atmosphere. The quantity of pyrolyzate ( $\mathrm{mg} \mathrm{HC} / \mathrm{g}$ rock) generated from kerogen during gradual heating in a helium stream was normalized to TOC, to give the hydrogen index $\left(\mathrm{HI}=\mathrm{S}_{2} \times 100 / \mathrm{TOC}\right.$; in $\mathrm{mg} \mathrm{HC} / \mathrm{g}$ TOC) [17].

In this study, some geochemical data about mudstone and oil shale to construct the logging identification model were taken from [18], and the depth was confirmed or corrected before model construction. 


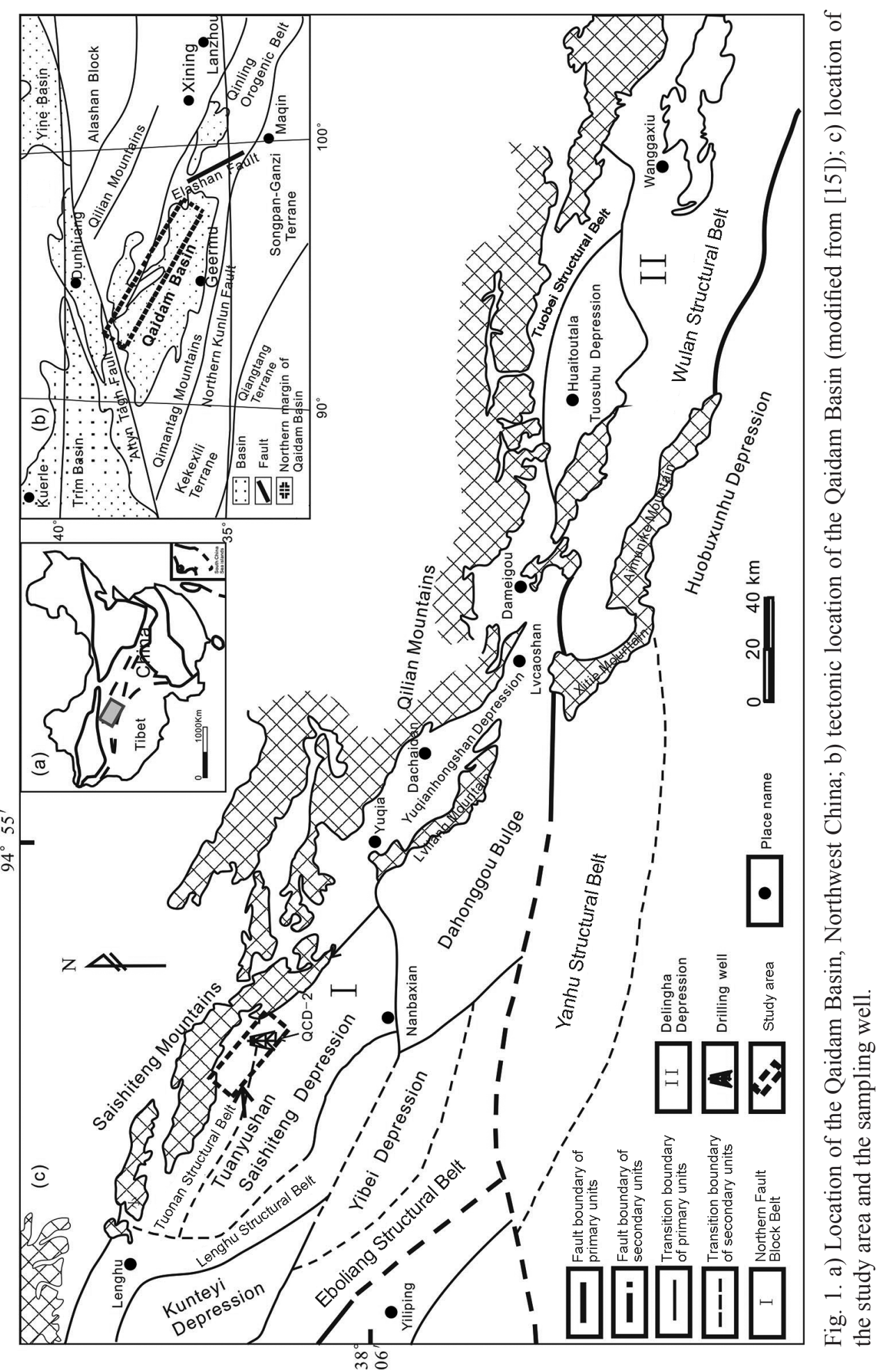




\section{Characteristics of oil shale}

The primary lithology of the Shimengou Formation shale is grey-black mudstone, silty mudstone and siltstone. Oil shale in $\mathrm{J}_{2} \mathrm{Sh}^{2}$ is grey-black and grey-brown (Fig. 2a). Horizontal and rhythmic beddings are widely developed (Fig. 2b). Oil shale and grey-black mudstone in this section have similar macroscopic characteristics, but their TOC and oil yields are different.

(a)

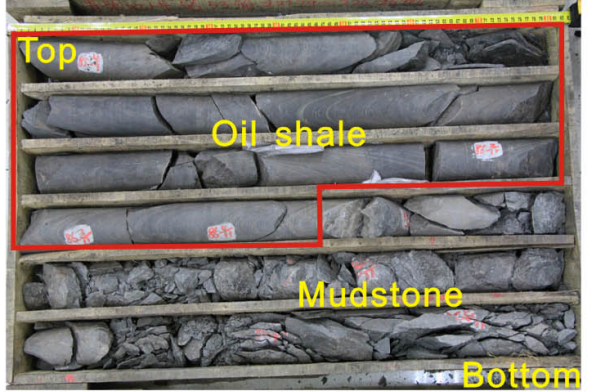

Mudstone and oil shale from $\mathrm{J}_{2} \mathrm{Sh}^{2}$, 226.23-230.43 m (b)

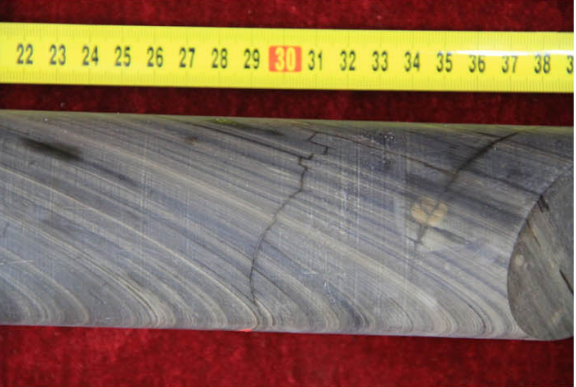

Rhythmic bedding in oil shale, $169.5 \mathrm{~m}$

Fig. 2. Lithologic characteristics of oil shale deposited in $\mathrm{J}_{2} \mathrm{Sh}^{2}$.

Table. Organic geochemical and industrial characteristics of oil shale in the northern Qaidam Basin

\begin{tabular}{|c|c|c|c|c|c|c|c|c|c|}
\hline Stratum & \multicolumn{2}{|c|}{$\begin{array}{l}\text { Depth, } \\
\text { m }\end{array}$} & $\begin{array}{c}\mathrm{S}_{1} \\
\mathrm{mg} / \mathrm{g}\end{array}$ & $\begin{array}{c}\mathrm{S}_{2} \\
\mathrm{mg} / \mathrm{g}\end{array}$ & $\begin{array}{c}\mathrm{HI}, \\
\mathrm{mg} \mathrm{HC/}\end{array}$ & $\underset{{ }^{\circ} \mathrm{C}}{\mathrm{Tmax},}$ & $\begin{array}{l}\text { TOC, } \\
\text { wt } \%\end{array}$ & $\begin{array}{c}\text { Oil yield, } \\
\text { wt } \%\end{array}$ & $\begin{array}{l}\text { Density, } \\
\mathrm{g} / \mathrm{cm}^{3}\end{array}$ \\
\hline \multirow{10}{*}{$\mathrm{J}_{2} \mathrm{Sh}^{2}$} & \multirow{10}{*}{$\begin{array}{c}\text { Well } \\
\text { QCD-2 }\end{array}$} & 169.3 & 0.24 & 65.71 & 678.82 & 437 & 9.68 & 6.5 & - \\
\hline & & 171.1 & 0.70 & 34.67 & 549.45 & 433 & 6.31 & 3.8 & - \\
\hline & & 172.0 & 0.17 & 84.22 & 735.55 & 433 & 12.88 & 7.2 & 1.99 \\
\hline & & 178.5 & 0.21 & 97.92 & 842.69 & 429 & 11.32 & 8.0 & - \\
\hline & & 182.0 & 0.52 & 69.67 & 705.88 & 435 & 9.87 & 6.3 & 1.87 \\
\hline & & 192.1 & 1.26 & 71.42 & 850.23 & 440 & 8.4 & 6.1 & 2.0 \\
\hline & & 176.1 & 0.21 & 52.21 & 523.50 & 435 & 6.67 & 4.3 & 1.84 \\
\hline & & 179.1 & 0.12 & 46.54 & 624.70 & 430 & 7.45 & 4.4 & 1.92 \\
\hline & & 183.58 & 0.45 & 47.83 & 607.75 & 433 & 7.87 & 4.2 & - \\
\hline & & 225.9 & 1.82 & 91.61 & 902.51 & 430 & 10.15 & 5.5 & 1.87 \\
\hline
\end{tabular}


Oil shale grading is defined by Liu et al. [19] as shale with an oil yield $>3.5 \%$ and TOC $>5.0 \%$. The TOC content of oil shale samples from $\mathrm{J}_{2} \mathrm{Sh}^{2}$ ranges from 6.3 to $12.9 \mathrm{wt} \%$ (average $9.0 \mathrm{wt} \%$ ). The $\mathrm{S}_{1}+\mathrm{S}_{2}$ content ranges from 35 to $98 \mathrm{mg} / \mathrm{g}$ (average $49 \mathrm{mg} / \mathrm{g}$ ). HI values vary between 550 and $903 \mathrm{mg} \mathrm{HC} / \mathrm{g}$ TOC (average $732 \mathrm{mg} \mathrm{HC} / \mathrm{g}$ TOC; Table). The organic matter of oil shale is of Type I and Type $\mathrm{II}_{1}$ (Fig. 3a, 3b), indicating that its main sources are algae and other aquatic organisms. Tmax is from $429^{\circ} \mathrm{C}$ to $440{ }^{\circ} \mathrm{C}$. The TOC of mudstone and carbonaceous mudstone samples from $\mathrm{J}_{2} \mathrm{Sh}^{2}$ ranges from 1.1 to $6.8 \mathrm{wt} \%$ (average $4.1 \mathrm{wt} \%$; data from [18]). HI values vary between 94 and $845 \mathrm{mg} \mathrm{HC} / \mathrm{g}$ TOC (average $437 \mathrm{mg} \mathrm{HC} / \mathrm{g}$ TOC). The organic matter is dominated by Type $\mathrm{II}_{1}$, followed by Type I. Tmax is from $423{ }^{\circ} \mathrm{C}$ to $439^{\circ} \mathrm{C}$. The oil yield of both oil shale and mudstone demonstrates a good linear relationship with TOC, $\mathrm{R}^{2}$ being 0.83 (Fig. 3c).

The TOC and hydrocarbon generation potential of $\mathrm{J}_{2} \mathrm{Sh}^{2}$ oil shale are higher than those of mudstone, though both display similar macroscopic and organic geochemical characteristics, indicating that oil shale undergoes a certain change.

(a)

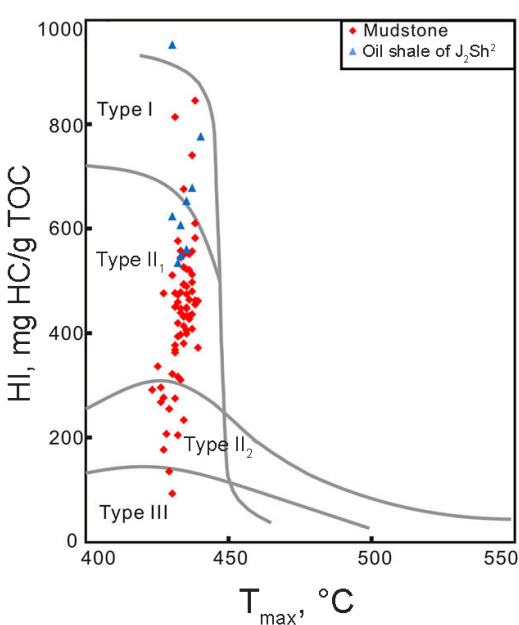

(c)

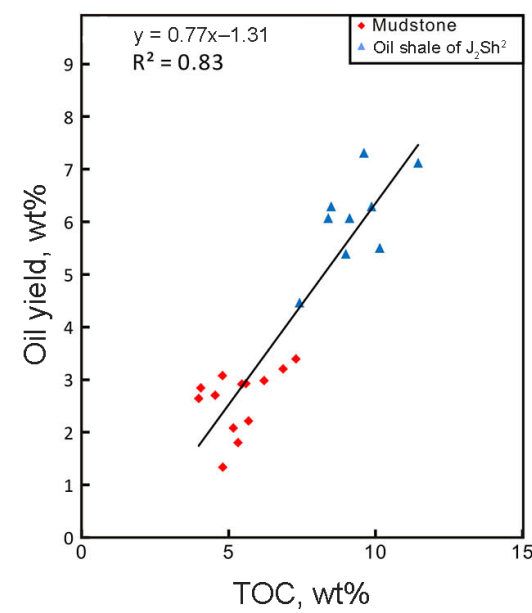

(b)

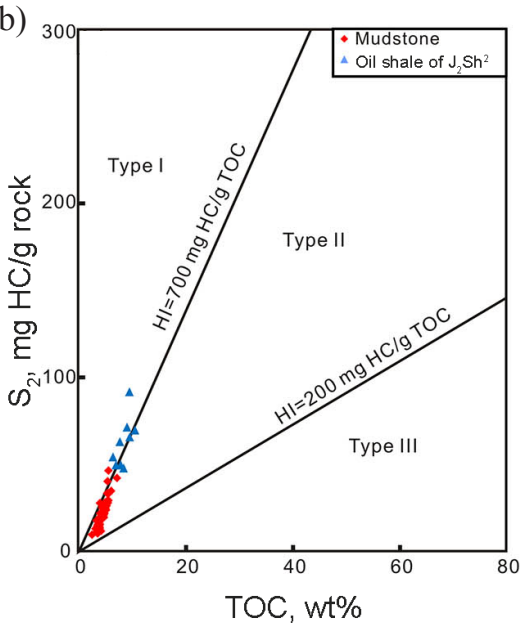

Fig. 3. a) Plot of HI vs Tmax; b) plot of $\mathrm{S}_{2}$ vs TOC, outlining the types of kerogen in oil shale samples from the $\mathrm{J}_{2} \mathrm{Sh}^{2}$ area of the Shimengou Formation; c) cross-plot of TOC vs oil yield of oil shale from the $\mathrm{J}_{2} \mathrm{Sh}^{2}$ area of the Shimengou Formation. 


\section{Logging evaluation}

\subsection{Logging characteristics of oil shale}

Oil shale is mainly composed of terrigenous clastic and organic matter, which have different logging responses. The content of organic matter determines the quality of oil shale and is clearly reflected on the logging curves of resistivity, density and natural gamma [4]. Therefore, this paper establishes a logging recognition model and evaluates its potential use for $\mathrm{J}_{2} \mathrm{Sh}^{2}$ oil shale identification.

\subsubsection{Natural gamma-ray logging}

Fine-grained sedimentary rocks usually have a high content of clay minerals. Compared with clastic minerals, the specific surface area of clay minerals and their capacity to adsorb radioactive elements are higher [7]. In comparison with mudstone and siltstone with low organic carbon content, the clay minerals content of oil shale is higher [13], so, its natural gamma is high. However, the radioactive elements content of sedimentary rocks is greatly affected by the geological conditions of the source area, hence, this content varies significantly by region. In addition, the paleo-oxygen facies of sedimentary environments also considerably influences the content of one of the major radioactive elements, uranium. The changes of the sedimentary environment in the stratum can cause the vertical change of the natural gamma logging value in it [20]. It is worth noting that in comparison with mudstone, the natural gamma value of oil shale in the study area is relatively low. This conflicts with the general understanding that oil shale adsorbs radioactive elements due to its high content of organic matter. The same can be observed in oil shale samples from the Yuka area of the northern Qaidam Basin [21, 22]. This may be caused by the low content of radioactive elements in the source rock during the sedimentation period of the Shimengou Formation. The natural gamma value of oil shale in the study area is negatively correlated with TOC content, $\mathrm{R}^{2}=0.24$ (Fig. 4a). This linear relationship can be used to quantitatively identify oil shale.

\subsubsection{Resistivity logging}

Mudstone contained in sedimentary strata, except calcareous mudstone, tends to display low resistivity due to its high content of water. Many studies have shown clay minerals to exhibit a high capacity to adsorb organic matter. With increasing clay mineral content in sedimentary rocks, their organic matter content also increases [23]. In addition, in a warm and humid paleoclimate, the strong biological and chemical weathering causes the increase of clay mineral content in the sediment. The warm and humid climate is also conducive to the introduction of exogenous organic matter into the lake and improvement of its 


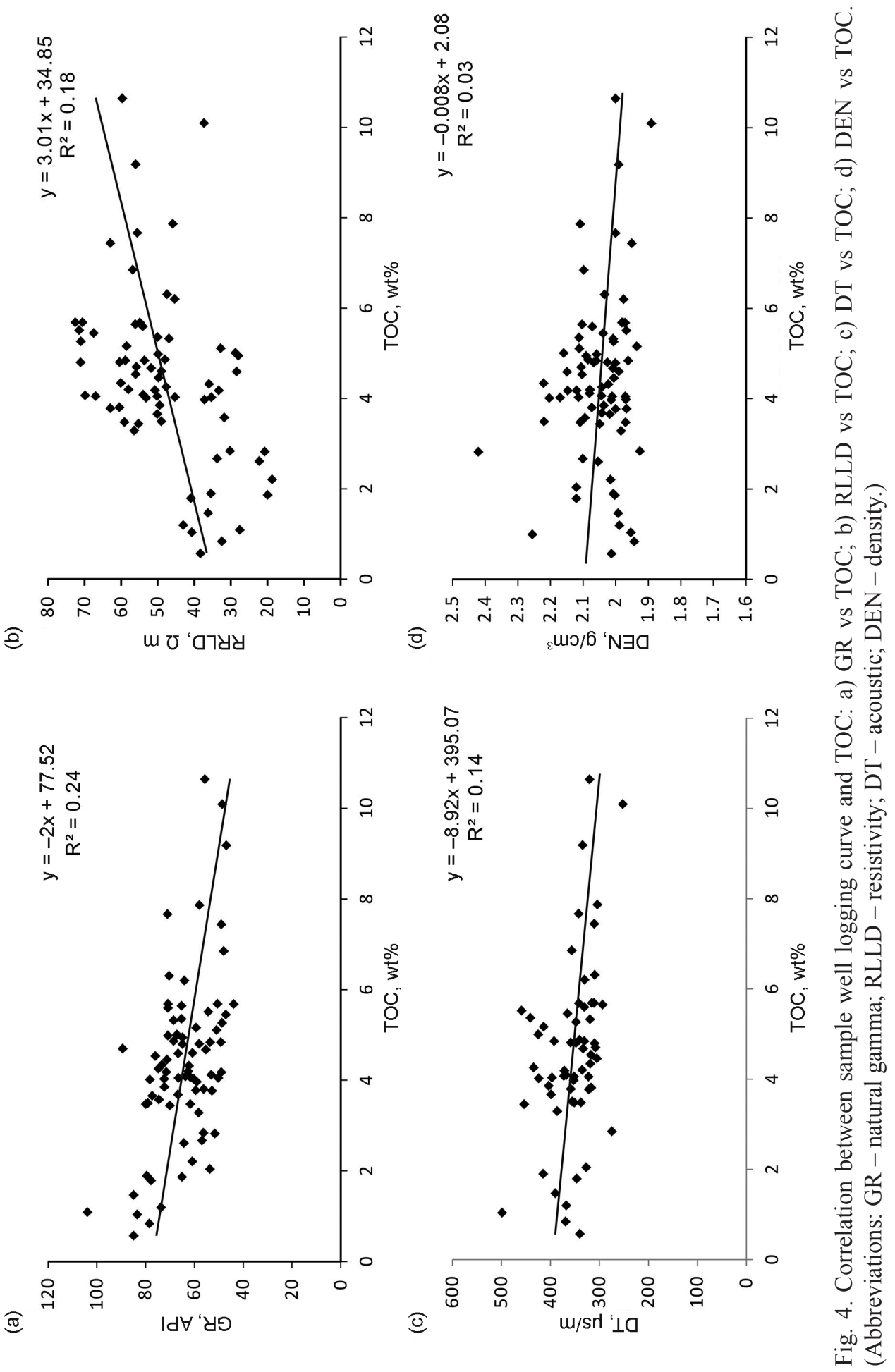


productivity. As a result, the sediment's organic matter content increases. With increasing content of organic matter, bound water in clay pores will be partly replaced by it [24], while the organic conductivity is extremely low, hence, the resistivity of oil shale and coal seams is high. The resistivity of sediments in the study area is linearly and positively correlated with their TOC content, $\mathrm{R}^{2}$ being 0.18 (Fig. $4 \mathrm{~b}$ ). This relationship can be used as one of the main parameters for logging evaluation.

\subsubsection{Acoustic travel time logging}

In conventional geological formations, sonic logging is affected by lithology, fluid properties and porosity. When the grain size of the sediment is fine, the clay mineral content is high and there is no brittle mineral, the sonic logging is mainly affected by pores and hydrocarbon fluids. However, oil shale has no larges pores and immature oil shale is not influenced by hydrocarbon fluids. Therefore, the sonic logging response of oil shale generally depends on the change of its composition [25]. The acoustic travel time of mudstone decreases as the burial depth increases, but organic matter is a medium that is not conducive to acoustic wave transmissions. The acoustic travel time of mudstone is longer than that of rock skeletons. Therefore, organic matter content is often negatively correlated with acoustic travel time. Acoustic travel time, however, is affected by the degree of borehole wall collapse. When using the logging data, it is therefore necessary to eliminate the logging values at the collapse site. The acoustic travel time measured within the study area is negatively correlated with TOC (Fig. 4c).

\subsubsection{Density logging}

The density of organic matter contained in a sedimentary rock is relatively low, about $1.0 \mathrm{~g} / \mathrm{cm}^{3}$, while the skeleton density of the sedimentary rock is relatively high, approximately $2.7 \mathrm{~g} / \mathrm{cm}^{3}$. With its high content in a source rock, the density of organic matter is low, and there exists an obvious negative linear correlation between the two. Therefore, the density logging is often used as one of the main parameters to evaluate the logging of hydrocarbon source rocks. However, within the study area, the correlation between density logging parameters and TOC content is not obvious (Fig. 4d). This may be due to faults and differential compaction, which contribute to an uneven distribution of the density of sediments. This conclusion can be confirmed by the frequent occurrence of the structural fracture zone and a wide formation dip angle (up to $67^{\circ}$ ). Therefore, the density logging is not used as one of the parameters for this logging prediction model. 


\subsection{Logging evaluation of oil shale}

\subsection{1. $\Delta \log \mathrm{R}$ recognition model}

The $\Delta \log \mathrm{R}$ method is used to superpose the porosity logging curve (acoustic, density and natural gamma-ray) on the logarized resistivity logging curve [8]. The overlapping segment represents the non-oil shale section, which is used as a baseline. In addition, the lithology at the baseline must be composed of finegrained sediments, such as mudstone or silty mudstone, from non-source rock. The TOC value at the baseline is equivalent to the background value, and the $\Delta \log \mathrm{R}$ value is equal to 0 . The superposition of natural gamma and resistivity curves enables distinguishing oil shale and can be used as the first choice for the $\Delta \log \mathrm{R}$ model, though siltstone displays a logging response similar to oil shale's in this model, which can interfere with the prediction results (Fig. 5a). However, the effect of acoustic travel time and density logging on lithologic differentiation is not as high as that of natural gamma (Fig. 5b, 5c), so these two models are not considered.

(a)
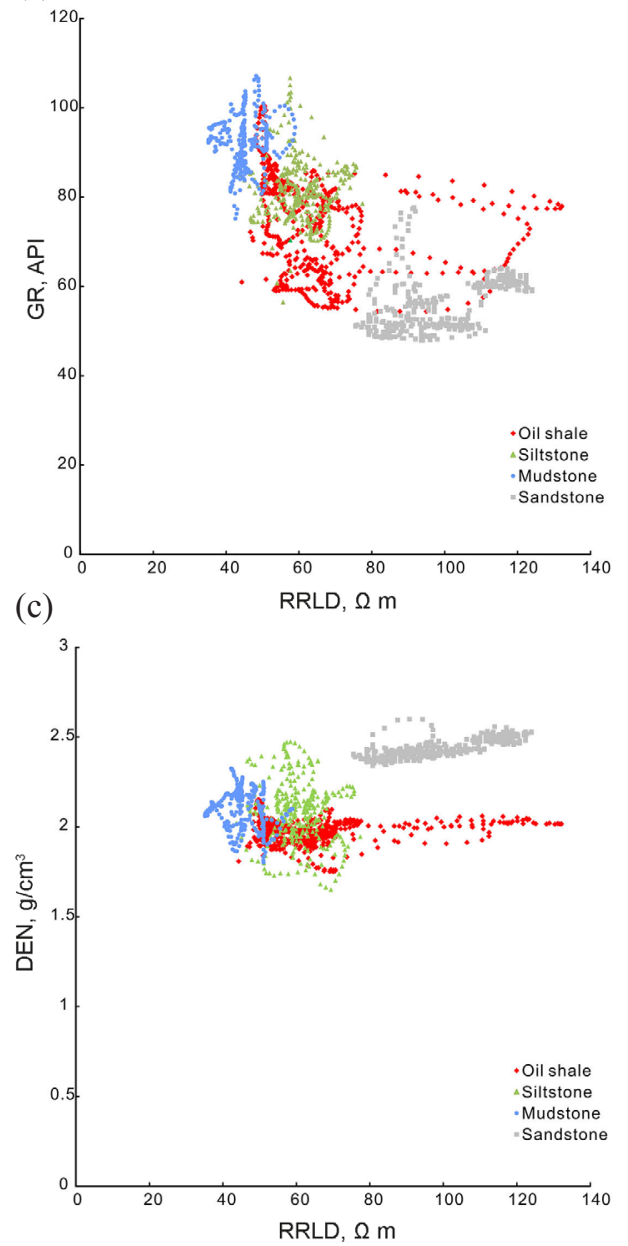

(b)

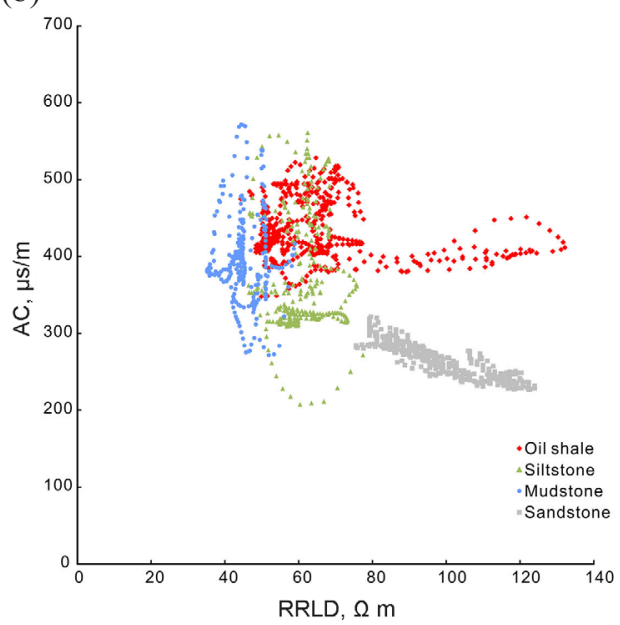

Fig. 5. Logging curve intersection diagram showing the intersections between: a) RLLD and GR, b) RLLD and AC, c) RLLD and DEN. (Abbreviations: RLLD - resistivity; GR - natural gamma; AC - acoustic travel time; DEN - density.) 


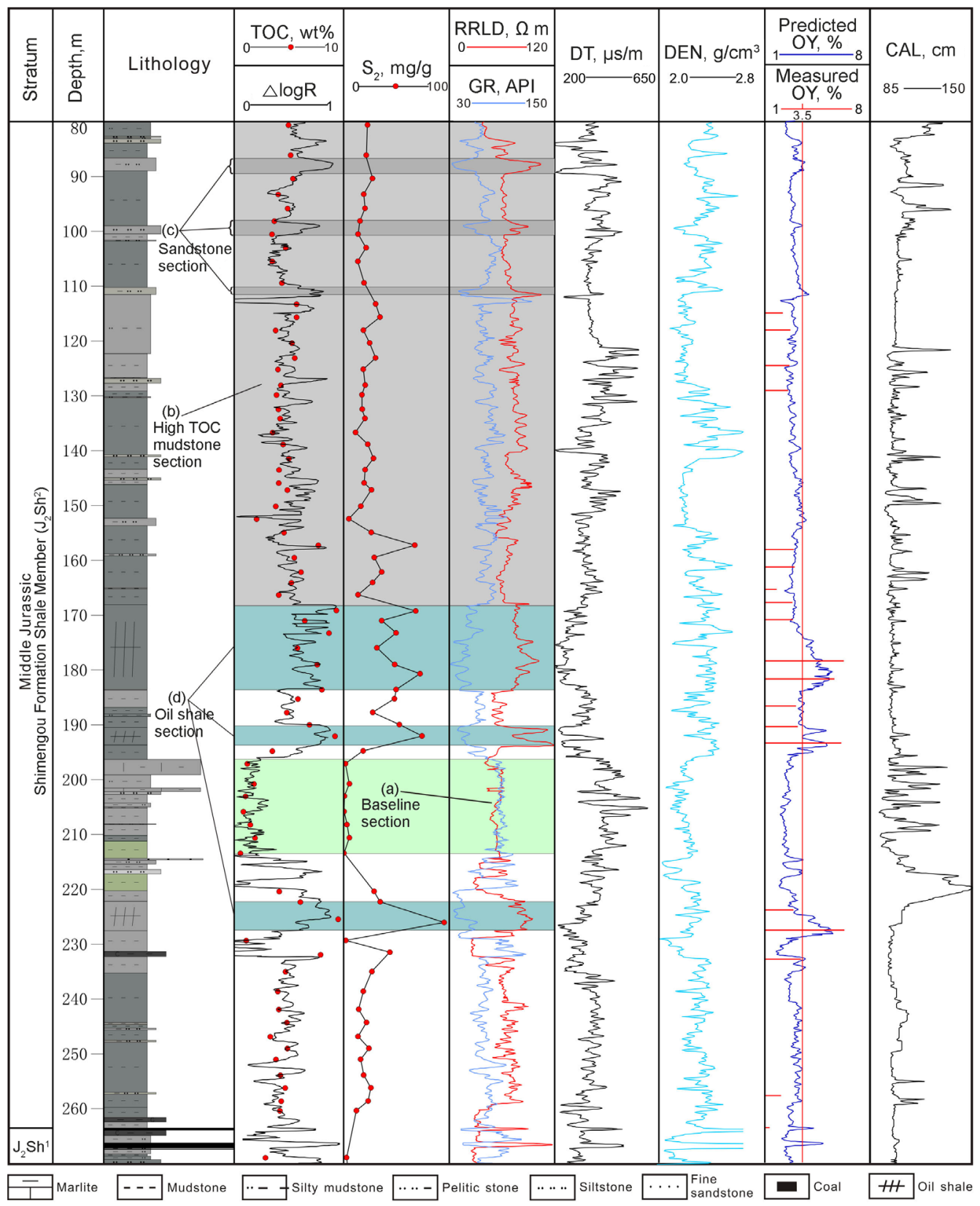

Note: RLLD - dual lateral resistivity logging; GR - natural gamma-ray logging; DT - acoustic logging; CAL - well diameter; DEN - density logging; OY - oil yield

Fig. 6. Lithology and logging interpretation of the sample from well QCD-2. 
A quantitative evaluation of TOC content using the $\Delta \log \mathrm{R}$ method can determine the baseline, which is the zero point of this model. The TOC of mudstone and siltstone samples ranges from 0.5 to $6.8 \mathrm{wt} \%$ (average $4.0 \mathrm{wt} \%$ ). The baseline is selected at the point of the lowest TOC of the fine-grained rocks section where it is between 0.5 and $1.9 \mathrm{wt} \%$ (Fig. 6a). The empirical $\Delta \log \mathrm{R}$ formula is as follows:

$$
\Delta \log \mathrm{R}=\log \left(\mathrm{R} / \mathrm{R}_{\text {baseline }}\right)+\mathrm{K}\left(\mathrm{GR}-\mathrm{GR}_{\text {baseline }}\right),
$$

where $\Delta \log \mathrm{R}$ represents the value differences between the logarized resistivity curve and the natural gamma curve; $\mathrm{R}_{\text {baseline }}$ and $\mathrm{GR}_{\text {baseline }}$ represent the baseline $\log$ values of the resistivity curve and the natural gamma curve, respectively; $\mathrm{R}$ represents the resistivity value, $\Omega \cdot \mathrm{m}$; GR represents the natural gamma value, in American Petroleum Institute (API) units; and the superposition coefficient $\mathrm{K}=0.02$ is based on the ratio of 50 API to one resistivity cycle, mentioned above as one empirical parameter. The resistivity curve of the baseline section ranges from 28 to $58 \Omega \cdot \mathrm{m}$, with an average of $38 \Omega \cdot \mathrm{m}$; the average is used as the baseline value, $\mathrm{R}_{\text {baseline }}=38$ (Fig. 6a). The natural gamma-ray curve of the baseline section is from 59 to $87 \mathrm{API}$, with an average of $80 \mathrm{API}$; the average is used as the baseline value, $\mathrm{GR}_{\text {baseline }}=75$ (Fig. 6a). As the TOC of oil shale in the study area is negatively correlated with GR, $\mathrm{K}$ is -0.02 . Accordingly, the $\Delta \log \mathrm{R}$ calculation formula for the study area can be expressed as follows:

$$
\Delta \log R=\log (\mathrm{R})-0.02 \mathrm{GR}-0.08
$$

On this basis, combined with the TOC test results, the regression fitting of $\triangle \log \mathrm{R}$ and TOC is written as follows:

$$
\mathrm{TOC}=4.6859 * \Delta \log \mathrm{R}+0.89,
$$

while $\mathrm{R}^{2}=0.67$

There is a good correlation between TOC and $\Delta \log \mathrm{R} ; \mathrm{R}^{2}$ is 0.67 and the mean absolute deviation (MAD) is $0.95 \mathrm{wt} \%$ (Fig. 7a). The TOC prediction results for well QCD-2 of $\mathrm{J}_{2} \mathrm{Sh}^{2}$ were obtained by introducing the above formula into the logging curve (Fig. 6). Within $\mathrm{J}_{2} \mathrm{Sh}^{2}$, the composition of organic-rich mudstone is similar to that of oil shale, except there is a difference in organic matter content between the two. Therefore, the $\Delta \log R$ amplitude of mudstone is similar to or slightly narrower than that of oil shale (Fig. 6b). Siltstone and argillaceous siltstone as mudstone interlayers also have a high resistivity and a low natural gamma (Fig. 6c), while their log response is similar to oil shale's (Fig. 6d). The prediction results for siltstone and argillaceous siltstone give evidence of higher TOC values, indicating that the $\Delta \operatorname{logR}$ model for oil shale prediction has certain limitations and should be combined with appropriate joint judgment logging curves to eliminate the other rocks' interference with prediction. 
(a)

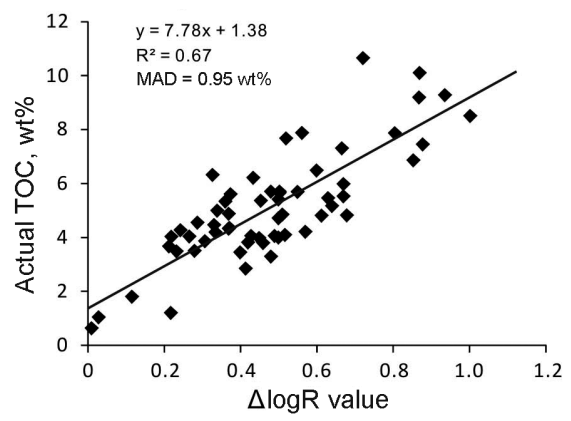

(b)

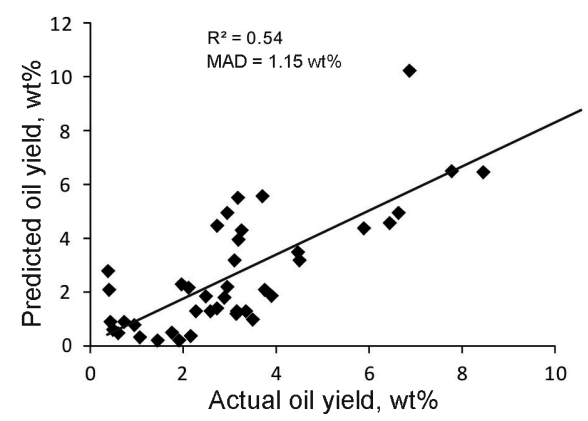

Fig. 7. Relevance of logging prediction model: a) $\Delta \log R$ identification model; b) stepwise regression model.

\subsubsection{Stepwise regression model}

In order to eliminate the siltstone and argillaceous siltstone's interference with the identification of oil shale resources, a stepwise regression model to determine the oil yield on the basis of oil shale logging was established, to improve the accuracy of oil shale identification through logging. The stepwise regression model is an improved form of multivariate regression modelling that comprehensively considers resistivity, natural gamma, acoustic travel time and density logging curves, screens out parameters that reflect significant changes in organic matter content, and establishes a regression equation. This method can effectively introduce appropriate logging parameters and discard irrelevant ones. The combination of log parameters can make full use of the relevant information a suitable parameter carries to improve the model's recognition ability [12]. Resistivity, natural gamma, acoustic travel time and density are identified as $a, b, c$ and $d$, respectively, and the 14 combined parameters are identified as follows: $a, b, c, d, a^{2}, b^{2}, c^{2}, d^{2}, a b, a c, a d, b c, b d$ and $c d$. In order to explore the causal relationships between these parameters, it is necessary to maintain the original dimension rather than normalise the data. In the stepwise regression model using the above parameters, oil yield is considered as a dependent variable. The oil yield of oil shale can then be directly predicted through this model as follows:

$$
T^{\mathrm{a}}=0.0004129 a c-0.00131 b^{2}+3.979,
$$

where $T^{\mathrm{a}}$ denotes oil yield. $\mathrm{R}^{2}=0.54$.

Differently from resistivity, natural gamma and acoustic travel time, density logging was not included in the model due to the low correlation $\left(\mathrm{R}^{2}=0.03\right)$ between TOC and density of mudstone (Fig. $\left.4 \mathrm{~d}\right)$, presumably owing to the differential compaction because of fracture. $\mathrm{P}$ value is an indicator of 
significance of the regression model in the Fisher test, so, the lower the P value is, the lower is the probability that the model's recognition ability is caused by contingency. It is generally believed that $\mathrm{P}<0.05$ is significant, while $\mathrm{P}<0.01$ is very significant. The $\mathrm{P}$ value of the Fisher test for the stepwise regression model established in this study is 0.00751 , and the significance test shows the model to be highly effective. Its MAD is $1.15 \mathrm{wt} \%$ and $\mathrm{R}^{2}$ is 0.54 (Fig. 7b). The predictive ability of the stepwise regression model is lower than that of the $\Delta \log \mathrm{R}$ model, though the former can successfully avoid the siltstone interlayers' interference with prediction and improve recognition accuracy (Fig. 6). Based on this finding, the stepwise regression model was used to evaluate oil shale resources in the study area.

\subsubsection{Evaluation results}

The stepwise regression model was applied to the identification and prediction of oil shale resources in the study area, and the results were compared with oil yield test results for oil shale samples from two full-core wells (Fig. 8a, $8 \mathrm{~b})$. The model proved to be effective for identifying and predicting the area's oil shale resources $\left(\mathrm{R}^{2}=0.49\right)$ (Fig. 8c). Based on the prediction results for 36 wells, the contour map for oil shale accumulated thickness and weighted average oil yield was drawn, showing the thickness to be between 5 and $25 \mathrm{~m}$ (Fig. 9a). High cumulative thickness values are characteristic of the northwestern, central and southeastern regions of the study area. The contour map for oil yield indicates that oil shale is primarily of medium quality (Fig. $9 \mathrm{~b})$. The trend of oil shale floor burial isoline shows its burial depth to be mostly less than 1,000 $\mathrm{m}$ and the stratum dip in the study area's southeastern region to be large, resulting in a significant change in burial depth that ranges from 200 to $500 \mathrm{~m}$ (Fig. 9c).

According to the general requirements for solid mineral exploration (GB/T13908-2002) [26], the volume method is used to estimate oil shale resources. The calculation method is as follows:

$$
\text { Quantity of oil resource }=\mathrm{D} \iiint \mathrm{f}(\mathrm{x}, \mathrm{y}, \mathrm{z}) \mathrm{dQ} \text {, }
$$

where $\mathrm{x}$ and $\mathrm{y}$ represent the area and thickness of oil shale, respectively; the integral represents the volume of oil shale; and $\mathrm{z}$ represents oil yield. According to the density measurement results of the drainage method, the density of oil shale changes little, so the average value $d=1.95$ is taken for resource estimation. The above calculation process is carried out in Double Fox software using the interpolation method.

Based on the calculation results, the resource volume of oil shale in the study area is 201 million $\mathrm{m}^{3}$, indicating that it contains 392 million tons of oil shale, or 24 million tons of converted shale oil. 
(a)

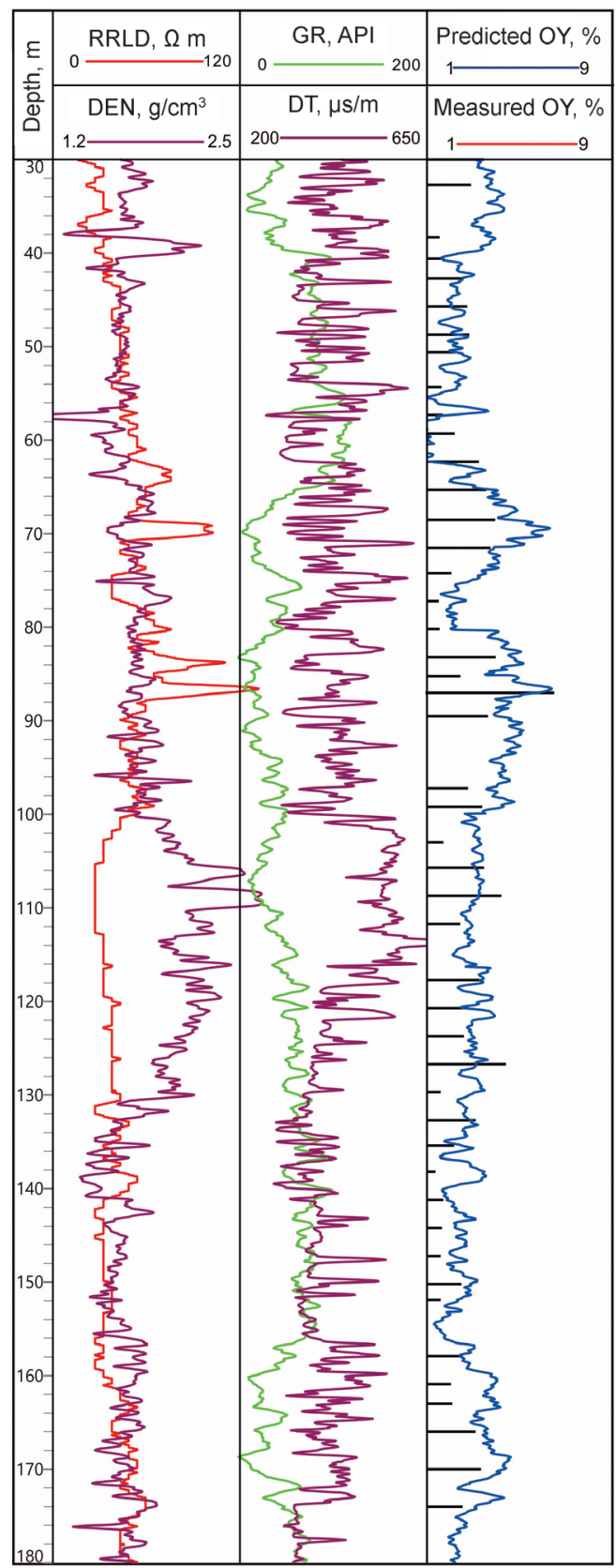

(b) Well KT-23

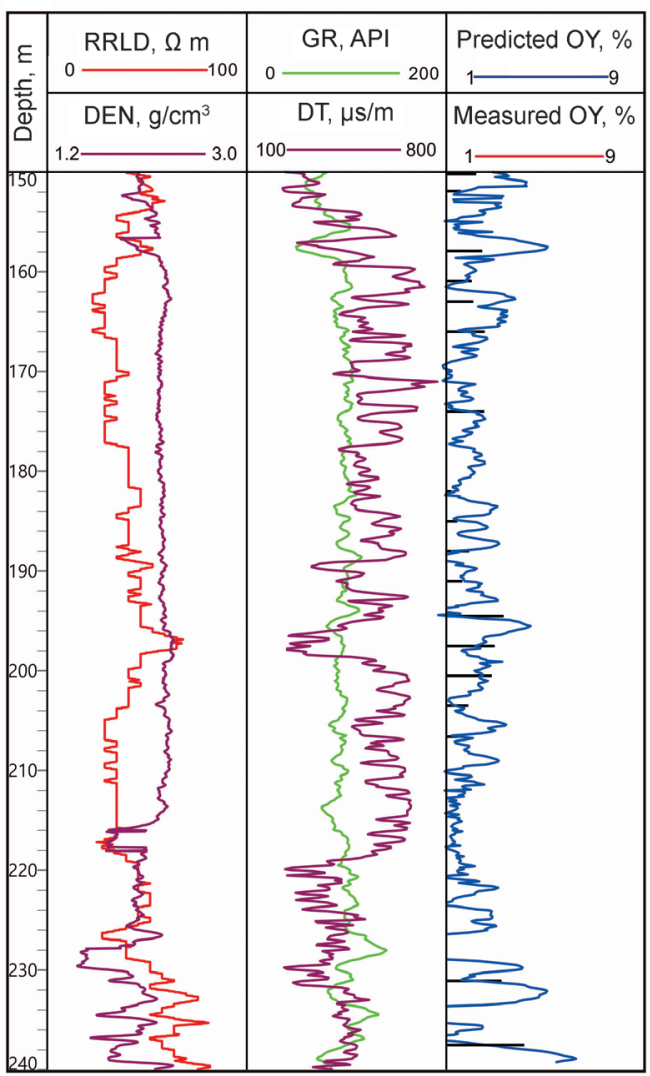

(c)

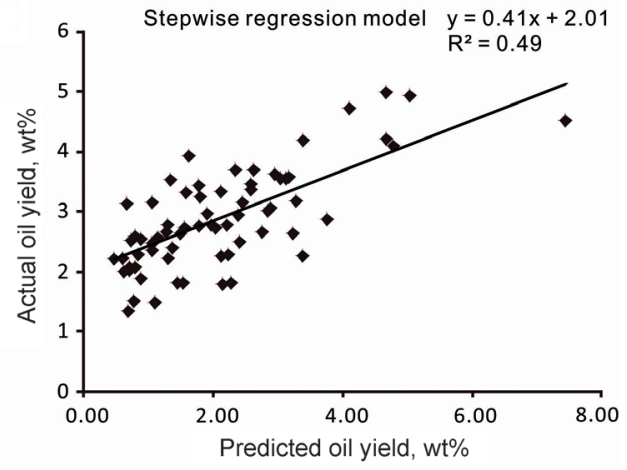

Fig. 8. a) Well Y24-2 model verification; b) well KT-23 model verification; c) correlation of the stepwise regression model of measured wells. 
(a)

(b)

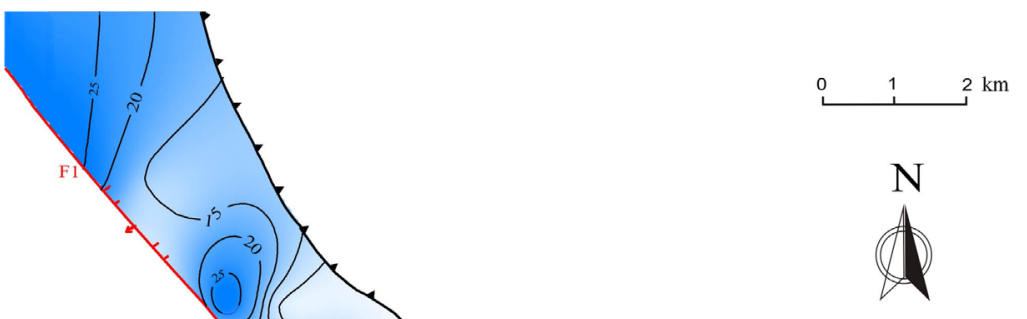

(c)
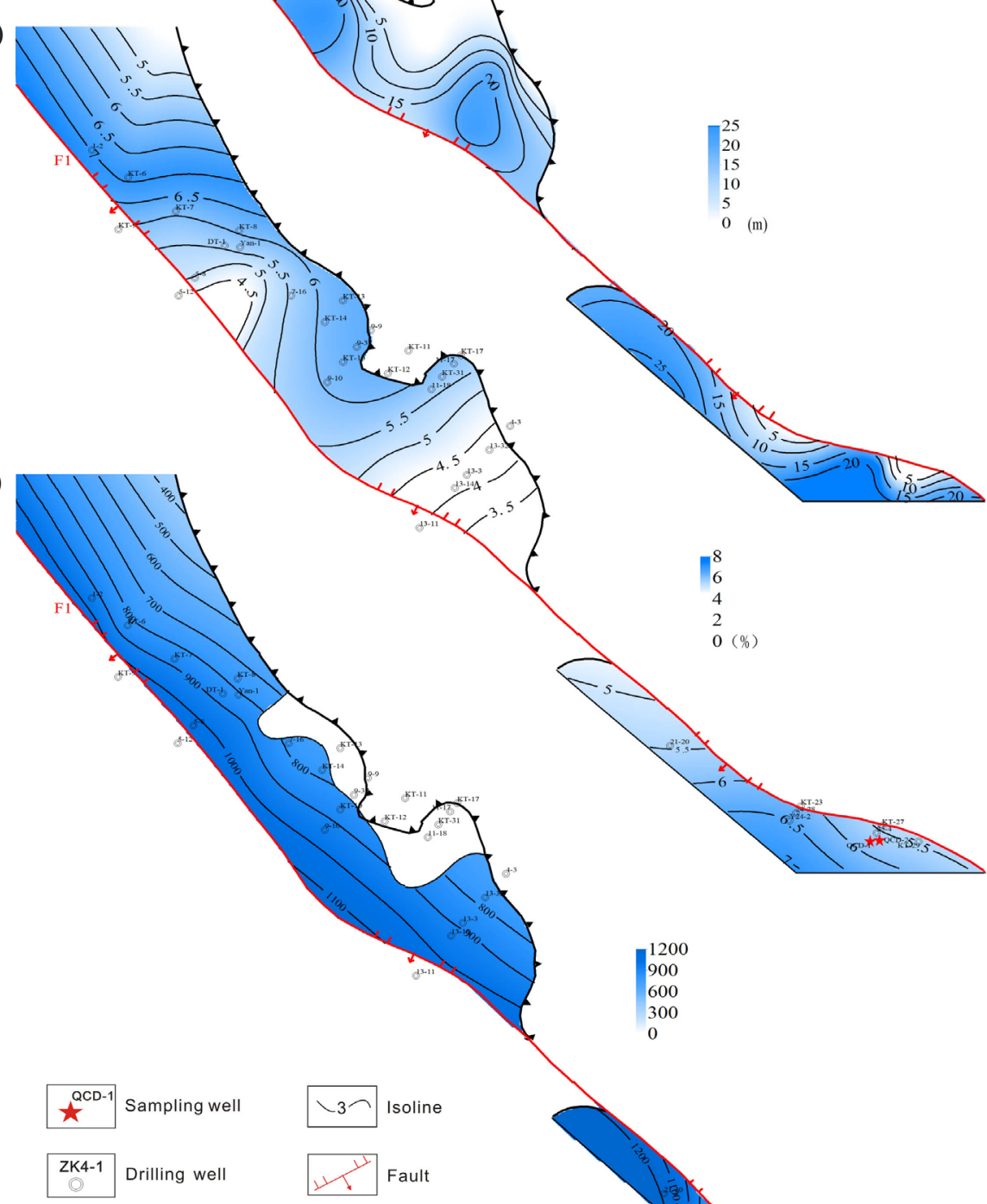

- Denudation boundary

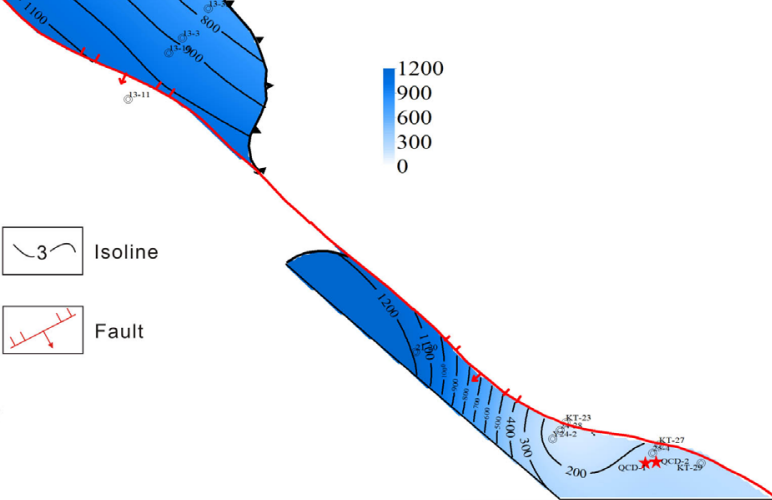

Fig. 9. a) Cumulative thickness contour map of oil shale from $\mathrm{J}_{2} \mathrm{Sh}^{2}$; b) contour map of oil shale oil yield; c) contour map of oil shale burial depth. 


\section{Conclusions}

1. Oil shale in the Shimengou Formation is characterised by high resistivity, high acoustic travel time and relatively low natural gamma, with one low and two high logging responses. Total organic carbon content is positively correlated with resistivity and acoustic travel time and negatively correlated with natural gamma, while there is no obvious correlation with density logging.

2. Based on the $\log$ response characteristics of oil shale, the $\Delta \log R$ identification model and the stepwise regression model are established. The mean absolute deviation of the $\Delta \log \mathrm{R}$ model is $0.95 \mathrm{wt} \%$ and the coefficient of determination, $\mathrm{R}^{2}$, is 0.67 , for the stepwise regression model the respective values are $1.15 \mathrm{wt} \%$ and 0.54 . Of the two models, the $\Delta \operatorname{logR}$ model has a higher prediction ability, but its results are disturbed by siltstone. The stepwise regression model can eliminate the siltstone's interference and make the prediction results more accurate.

3. According to the prediction results of the stepwise regression model and the logging curves for 36 wells, the cumulative thickness of oil shale in the Shimengou Formation is between 5 and $25 \mathrm{~m}$ and its burial depth is generally less than $1,000 \mathrm{~m}$. The Formation's total oil shale resource is 392 million tons, or 24 million tons of converted shale oil.

\section{Acknowledgements}

The authors would like to thank the National Natural Science Foundation of China $(41772092,41420088)$ and the Opening Foundation of Key Laboratory of Mineral Resources Evaluation in Northeast Asia, Ministry of Natural Resources (DBY-KF-19-13) for funding this research. We are very grateful to Professor Li Shuyuan and Professor Martin Liira for their valuable comments.

\section{REFERENCES}

1. Liu, Z. J., Meng, Q. T., Dong, Q. S., Zhu, J. W., Guo, W., Ye, S. Q., Liu, R., Jia, J. L. Characteristics and resource potential of oil shale in China. Oil Shale, 2017, 34(1), 15-41.

2. Schmoker, J. W. Determination of organic content of Appalachian Devonian shales from formation-density logs 1: Geologic notes. AAPG Bull., 1979, 63(9), 1504-1509.

3. Fertl, W. H., Rieke, H. H. Gamma ray spectral evaluation techniques identify fractured shale reservoirs and source-rock characteristics. J. Petrol. Technol, 1980, 32(11), 2053-2062.

4. Meyer, B. L., Nederlof, M. H. Identification of source rocks on wireline logs by 
density/resistivity and sonic transit time/resistivity crossplots. AAPG Bull., 1984, 68(2), 121-129.

5. Mendelson, J. D., Toksoz, M. N. Source rock characterization using multivariate analysis of log data. SPWLA 26th Annual Logging Symposium, 17-20 June 1985, Dallas, Texas, Paper UU.

6. Autric, A., Dumesnil, P. Resistivity, radioactivity and sonic transit time logs to evaluate the organic content of low permeability rocks. The Log Analyst, 1985, 26(3), 36-45.

7. Hussain, F. A. Source rock identification in the state of Kuwait using wireline logs. SPE Formation Evaluation, SPE Paper 15747, 1987, 477-488.

8. Passey, Q. R., Creaney, S., Kulla, J. B., Moretti, F. J., Stroud, J. D. A practical model for organic richness from porosity and resistivity logs. AAPG Bull., 1990, 74(12), 1777-1794.

9. Huang, Z., Williamson, M. A. Artificial neural network modelling as an aid to source rock characterization. Mar. Petrol. Geol., 1996, 13(2), 277-290.

10. Yang, Y., Aplin, A. C., Larter, S. R. Quantitative assessment of mudstone lithology using geophysical wireline logs and artificial neural networks. Petrol. Geosci., 2004, 10(2), 141-151.

11. Mahmoud, A. A. A., Elkatatny, S., Mahmoud, M., Abouelresh, M., Abdulraheem, A., Ali, A. Determination of the total organic carbon (TOC) based on conventional well logs using artificial neural network. Int. J. Coal Geol., 2017, 179, 72-80.

12. Hu, H. T., Lu, S. F., Liu, C., Wang, W. M., Wang, M., Li, J. J., Shang, J. H. Models for calculating organic carbon content from logging information: Comparison and analysis. Acta Sedimentol. Sin., 2011, 29(6), 1199-1205 (in Chinese with English abstract).

13. Jia, J. L., Liu, Z. J., Meng, Q. T., Sun, P. C., Chen, Y. C. Quantitative evaluation of oil shale based on well $\log$ and 3-D seismic technique in the Songliao Basin, Northeast China. Oil Shale, 2012, 29(2), 128-150.

14. Lu, J., Shao, L. Y., Ju, Q., Liu, T. J., Wen, H. J., Li, Y. H., Zhang, F .D., Gao, D. Y. Coal petrography variation in the sequence stratigraphic frame of the Jurassic coal measures of Dameigou mine area in Northern Qaidam Basin. Coal Geology and Exploration, 2009, 37(4), 9-14 (in Chinese with English abstract).

15. Li, M., Shao, L. Y., Liu, L., Lu, J., Spiro, B., Wen, H. J., Li, Y. H. Lacustrine basin evolution and coal accumulation of the Middle Jurassic in the Saishiteng coalfield, northern Qaidam Basin, China. J. Palaeogeogr., 2016, 5(3), 205-220.

16. ASTM D3904-80. Standard Test Method for Oil from Oil Shale. American Society for Testing and Materials, West Conshohocken, PA, 1984.

17. Espitalié, J., Laporte, J. L., Madec, M., Marquis, F., Leplat, P., Paulet, J., Boutefeu, A. Méthode rapide de caractérisation des roches mètres, de leur potentiel pétrolier et de leur degré d'évolution. Rev. I. Fr. Pétrol., 1977, 32(1), 23-42 (in French).

18. Meng, Q. T., Liu, Z. J., Sun, P. C., Xu, Y. B., Li, F., Bai, Y. Y., Xie, W. Q., Deng, S., Song, S., Wang, K. B., Xu, C. Characteristics and accumulation of 
Middle Jurassic oil shale in the Yuqia area, Northern Qaidam Basin, Northwest China. Oil Shale, 2018, 35(1), 1-25.

19. Liu, Z. J., Yang, H. L., Dong, Q. S., Zhu, J. W., Guo, W., Ye, S. Q., Liu, R., Meng, Q. T., Zhang, H. L., Gan, S. C. Oil Shale in China. Petroleum Industry Press, Beijing, 2009, 62-116 (in Chinese, summary in English).

20. Landais, P. Organic geochemistry of sedimentary uranium ore deposits. Ore Geol. Rev., 1996, 11(1-3), 33-51.

21. Xie, W. Q., Liu, Z. J., Xiao, L. J., Song, S., Liu, J. L. Oil shale resource potential of the Middle Jurassic Shimengou Formation in Yuka of the North Rim in Qaidam Basin. Special Oil and Gas Reservoirs, 2018, 25(5), 78-83 (in Chinese, summary in English).

22. Fan, J. J., Wang, Y. B., Li, Y. H. Log evaluation and target zone optimization of Jurassic oil shale in Yuqia Area. Well Logging Technology, 2016, 40(5), 617-622 (in Chinese, summary in English).

23. McCrossan, R. G. Resistivity mapping and petrophysical study of Upper Devonian inter-reef calcareous shales of central Alberta, Canada. AAPG Bull., 1961, 45(4), 441-470.

24. Kaiser, K., Zech, W. Dissolved organic matter sorption by mineral constituents of subsoil clay fractions. J. Plant Nutr. Soil Sc., 2000, 163(5), 531-535.

25. Sarmiento, R. Geological factors influencing porosity estimates from velocity logs. AAPG Bull., 1961, 45(5), 633-644.

26. GB/T13908-2002. General requirements for solid mineral exploration. The State Standards of the People's Republic of China, 2003 (in Chinese).

Presented by S. Li

Received July 11, 2019 